\title{
5. Mourning Missing Migrants
}

\author{
Ambiguous Loss and the Grief of Strangers \\ Giorgia Mirto, Simon Robins, Karina Horsti, Pamela \\ J. Prickett, Deborah Ruiz Verduzco ${ }^{7}$ and Victor Toom ${ }^{2}$
}

\begin{abstract}
While the term missing refers to various instances and practices, we focus on the bodies of deceased migrants that remain unidentified, and on the inability of families to mourn someone when there is no body to grieve for. We deploy some ethnographic fragments of how Italian communities sometimes mourn those who are buried without a name and we describe the many problems of mourning someone whose fate is unknown through a discussion of the notion of 'ambiguous loss'. Our contribution articulates some of the politics around deaths in migration by considering how missing migrants and their bodies are mourned in multiplicity.
\end{abstract}

Keywords: commemoration, memorial, politics, Mediterranean, implications of missing persons, lost

In case my son is dead, I'd like to bury him here and, at least, I'll be fixed and I'd have a place where I pray. Even bones, I'll bury them. The cemetery is in front of my house. Every morning, I wake up in front of it. I recite the Fatihah, I do this daily. I don't have any hostility towards death. At least, if he's brought back to me, I'd look through the window to see his grave and I'd say that he's there. (Ben Attia 2016:17)

1 The views expressed in this chapter are those of Deborah Ruiz Verduzco and her co-authors and do not necessarily reflect those of ICMP.

2 Corresponding author: toomvictor@gmail.com.

Cuttitta, P. \& Last, T. Border Deaths: Causes, Dynamics and Consequences of Migration-related Mortality. Amsterdam: Amsterdam University Press, 2020.

DOI: 10.5117/9789463722322_CHO5 
Funerals are solemn occasions where both personal and social meanings are constructed about the position of the dead person in family and society. They are rituals where mourning is organized in a formalized way, and where someone's body, her past life and her family are at the centre of attention. They represent a significant moment, a marker of a transition, where one can see that a body is without life; it is cold, does not breathe, and descends into the soil or moves into flame, silent and still. Such rituals accompany bereavement and facilitate mourning. Psychologists define the mourning of someone who is interred or cremated and to whom farewells can be said as 'uncomplicated bereavement' (DSM-5 2013). A funeral with a body is in contrast to mourning someone without one. In the absence of a body, mourning becomes extremely difficult if not impossible (Boss 2004; Wagner 2008; Rosenblatt 2015; Perl 2016).

While attempting to cross the Mediterranean and other borders globally, thousands of migrants have died in recent years. Their bodies are often lost; they are lost because their bodies sink to the ocean floor, or because they remain unidentified after washing ashore on Mediterranean coasts or being found as desiccated skeletons in the desert (Alonso and Nienass 2016; M'charek 2018). Although the task of mourning someone is never easy, it becomes even more difficult when there is no certainty and no closure (ICRC 2010; Berns 2011). The reality for family members whose kin have disappeared - who are missing their child, sibling, spouse or parent - is that there is both no certainty about their fate, and no body to bury or gravesite to visit.

The question then becomes how to mourn someone when there is no body, not even confirmation of death? We discuss this question by, first, providing ethnographic glimpses of work conducted in Italy. We demonstrate that anonymous strangers are sometimes mourned by local populations, and that migrants' bodies acquire a post-mortal political life that engages with the humanitarian tragedy witnessed in the Mediterranean and other border zones every day (see Chapter 4 and 6). For every unidentified or unrecovered body in some border region of the world there is a family somewhere else looking for news about their missing relative (SchwartzMarin and Cruz-Santiago 2016). In the next section, we focus on family members who are missing loved ones and have no knowledge of their fate or whereabouts, using 'ambiguous loss' as a conceptual lens to understand the unique challenges of mourning without a body (Boss 2004, 2018; Edkins 2011). In the concluding section, we ask if there are interventions that could address the unique challenges to mourning migrants who are lost in the Mediterranean. 


\section{Mourning dead, unidentified migrants}

Thousands have drowned in the Mediterranean, many ending up dead on the territories they hoped to reach alive. Because two of us did ethnographic work in southern Italy, the section's focus is also related to the developed practices of dealing with the many dead in that region. Because there is no national law stipulating how migrant dead bodies must be managed, recorded and buried, there is great diversity in handling the dead between Italian municipalities. ${ }^{3}$ While some approaches focus on embracing the bodies and humanizing them again, in other places the attitudes and practices of authorities responsible for the identification of unknown bodies and their burial have devalued human dignity (Tapella, Mirto and Last 2016; Albahari 2016; Robins, Kovras and Vallianatou 2014; see also Chapter 4). Through these different practices of burial and honouring of the unidentified bodies of migrants, different understandings of 'us' and 'them,' of 'our community' and of the 'other' are rendered (see Green 2012; Rygiel 2016). Some authors of this contribution have extensively and ethnographically attended to the practices of recovery, burial, mourning and memorialization of unidentified dead migrants by communities where bodies are found, and recorded a wide variety of responses, including private and public memorialization, neglect, and intense engagement (Horsti 2017; Mirto 2017). One locus of engagement is the cemeteries, which we regard as collective sacred places (Laqueur 2015). They are not only sites of complex cultural, civic and religious performances, but can also be regarded as archives where bodies often (but not always) become objects and subjects of meticulous record-keeping. Such archives are where relatives and friends who miss their kin and community members go to look for traces of them, to find them again (see also Kovras and Robins 2016). We discuss two types of engagement with the unknown graves of people who died attempting to enter the EU: individual/private practices; and collective/public practices.

When Giorgia Mirto conducted research at the Porto Empedocle Cemetery in Sicily, she recorded a migrant's grave containing the remains of a victim who became known as 'ITo43/052'. ${ }^{4}$ According to the Deaths at the Borders

3 Italian law entrusts the management of the dead to the jurisdiction of local city councils, but it doesn't state any relevant detail for border deaths bodies. See Decreto del Presidente della Repubblica 10 Settembre 1990, n. 285 Approvazione del Regolamento di Polizia Mortuaria. Electronic document, http://www.softwareparadiso.it/studio/lex-dpr285del9omortuaria.htm (accessed 10 December 2018).

4 For further information, see the series of intense photos about dead migrants and their post-mortal journeys recorded by Max Hirzel. His work, Migrant Bodies, is accessible at https:// maxhirzel.photoshelter.com/index. 
Database, ${ }^{5}$ her body was found at the location 34.359 N 12.3568 E, 53 nautical miles off Lampedusa on 18 June 2007 , and it was forensically examined and subsequently buried on 19 June 2007. From the forensic investigation, the level of decomposition indicated that she died approximately fifteen days before she was found. Authorities established that she drowned, that her height was 1.65 meters, and that she was of African ethnicity. Horrified by how the woman had died - her body decomposed and unidentified, missing any official recognition of death (such as a death certificate) - the cemetery caretaker kept telling Giorgia 'she's alone' and had planted roses on the grave (see Figure 5.1). Although she was a stranger, he cared for her body and grave.

\section{Figure 5.1 Roses planted by the cemetery caretaker on an unknown migrant woman's grave. Porto Empedocle, Sicily}

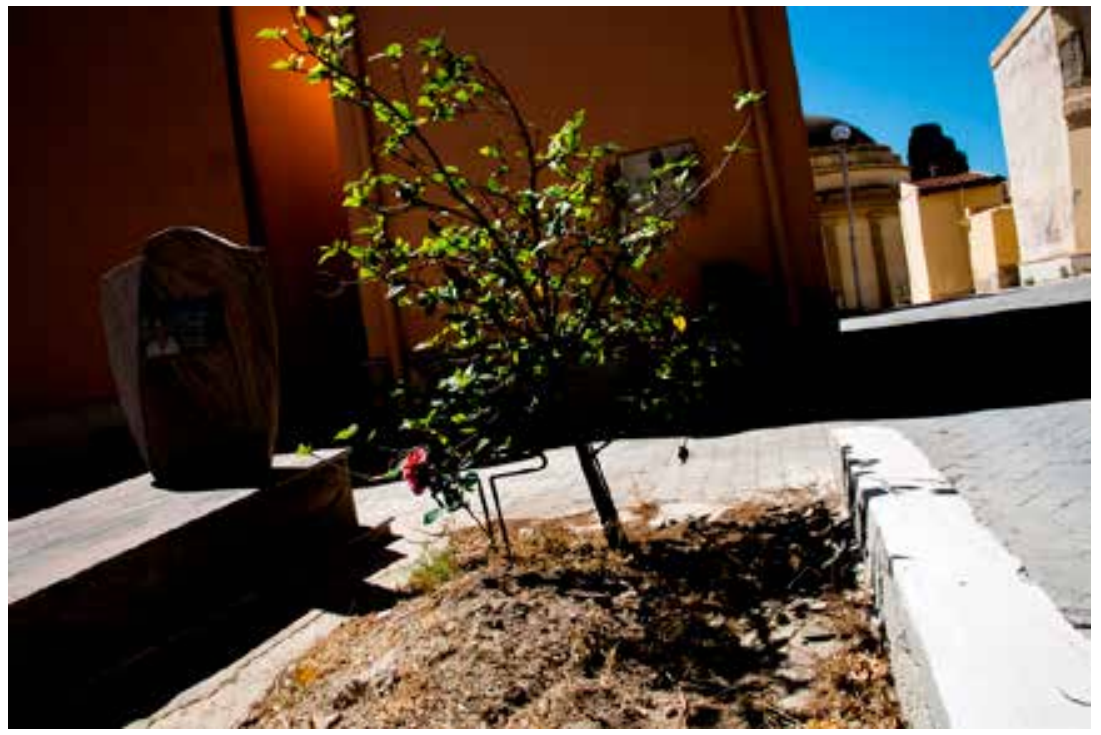

Photo: Max Hirzel

Mourning strangers is not uncommon in Sicily. Two local widows came to the cemetery not only to visit the graves of their late husbands but also to cry at the grave of the woman we know as ITo43/052. They complained to Giorgia that the woman - and the other unidentified drowned migrants in the cemetery - was left alone. The widows felt a moral obligation to pray for

5 The Deaths at the Borders Database can be accessed here: http://www.borderdeaths. org/?page_id=425 (accessed 22 November 2018). 
Figure 5.2 La speranza naufragata (Wrecked Hope), memorial created in 2015 for the memory of unknown migrants who died at sea. Catania cemetery, Sicily

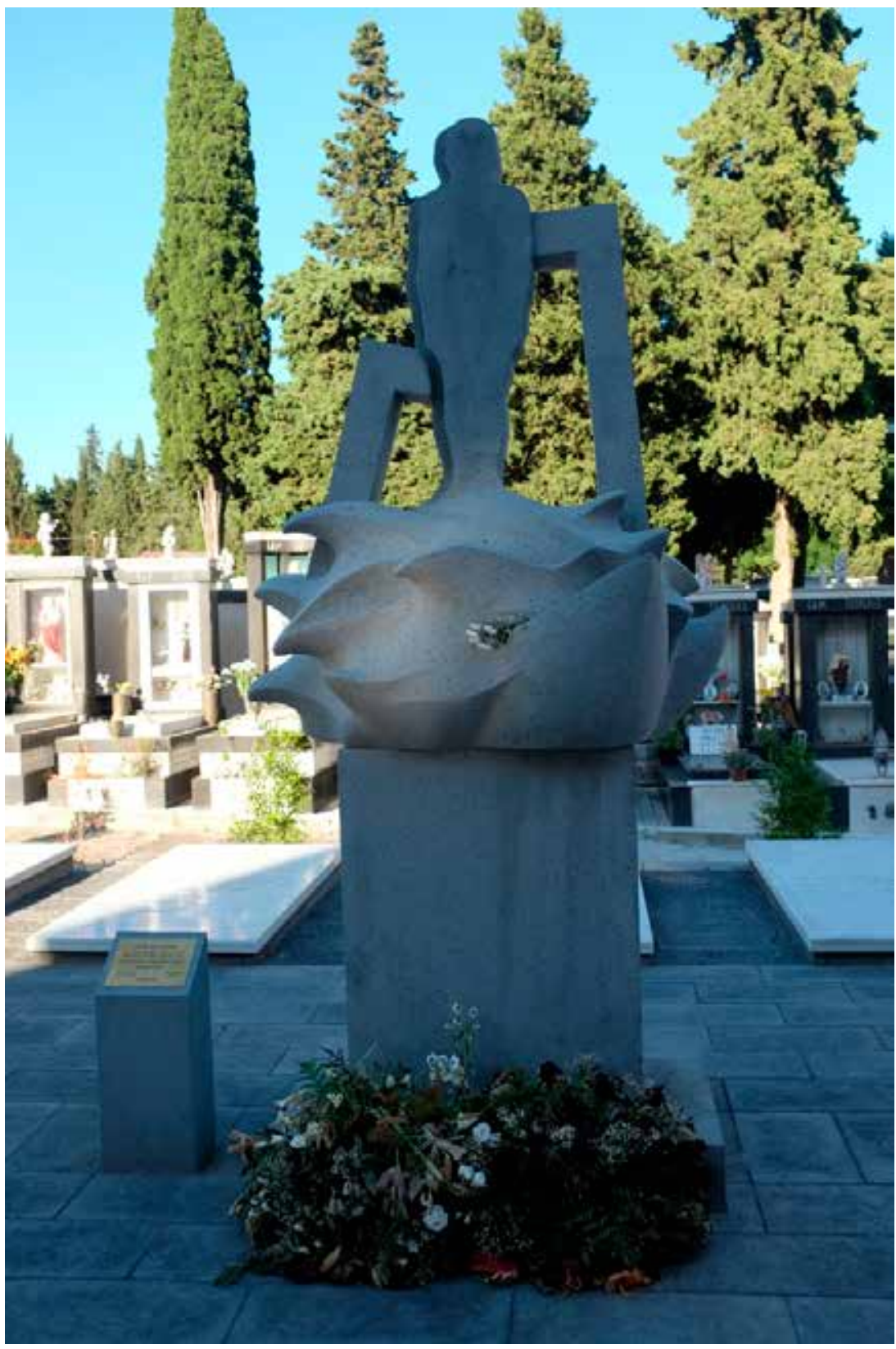

Photo: Karina Horsti 
the dead woman's soul. The widows referred to the migrants using Sicilian terms normally used for relatives: sangumeo and ciato di lu me cori, meaning 'my blood' or 'breath of my heart'. The rose planted by the cemetery caretaker and the prayers of the widows demonstrate that local residents adopt and integrate unidentified, unknown migrants, thereby effectively bridging the dualism of 'us' and 'other.' Their care for the dead reveals a profound appropriation of mourning and the subsumption of deceased migrants within their own community of deceased. Beyond this, the appropriation of mourning allows the application of the ritual practices for overcoming grief.

In addition to these examples of rather personal and private means of mourning, we also observed more publicly visible, communal practices of engagement with the unknown dead and their graves in Italy. One can witness many lasting memorials for the anonymous migrant dead that guide others about how to mourn border deaths, and they are located in for example Lampedusa and Catania (Horsti 2016, 2017; Horsti and Neumann 2017). One of those memorials is Speranza naufragata, or Wrecked Hope, located in the main cemetery of Catania and serving at least two purposes (see Figure 5.2). First, the memorial critiques the EU as not taking responsibility for irregular migration and thus leaving the nations and communities in the border zone to recover, process, manage, bury and mourn border fatalities on their own. Second, the memorial serves to demonstrate - under the spotlight of international media attention - Sicilian communities as a caring society (Horsti 2017). But more is going on as the many graves without a name also stimulate people to act.

In Italy, as well as in other global border zones (see e.g. De León 2015; Boudreaux 2016; Gibbings 2010), there is widespread public engagement and numerous interventions aimed at expressing solidarity with dead migrants. These collective actions articulate 'grief activism' that aims at transforming political practices from creating division and necropolitical violence into fostering communities and relationalities (Stierl 2016). Another form of intervention, coined 'cemetery activism' or 'grave activism' attempts to render dignity and visibility to the unknown dead and make apparent the phenomenon of fatal borders (Stierl 2016). Such interventionist performances produce materials and other traces that acknowledge the dead as individuals, confirming that they are publicly grievable (cf. Butler 2004). But there is another, darker side to this. Cemeteries, such as that in Lampedusa, have become tourist destinations: they attract visitors with many different objectives, including paying respect, taking selfies to be posted on Instagram and other digital platforms, or for educational purposes. Such 'dark tourism' has been associated with exploitation and objectification of the dead (Lennon 
and Foley 2000). Making more public the anonymous dead - a development that has accelerated since the 3 October 2013 disaster in Lampedusa - places them back in the polis and at the same time furthers their status as mute objects servicing wealthy European consumer or humanitarian desires.

\section{Ambiguous loss}

The woman with record number IT043/052 is not exceptional in the Mediterranean. Between 2014 and late 2018, close to 18,00o deaths were reported in the Mediterranean. ${ }^{6}$ Most recovered bodies remain unidentified; whose body it is is impossible to determine (Toom 2016). In such cases those persons are understood to be missing by their families; they don't know if they are dead or alive, only that they are gone (Edkins 2011). Ambiguous loss is 'a situation of unclear loss resulting from not knowing whether a loved one is dead or alive, absent or present' (Boss 2004: 554). Ambiguous loss occurs where a family member is psychologically present but physically absent. As a result, families of the missing are trapped between hope and despair, seeking an answer but fearing it will be the worst answer and consumed by not knowing; not knowing whether to await a phone call or a letter, or to presume their loved one is gone for ever (Boss 2004; Robins 2010). Whilst the missing can be remembered and commemorated, as long as their fate is not known they cannot be mourned and their relatives may struggle to go on with life (Perl 2016). Border deaths are a tragedy amplified by the social relations in which those who die are embedded. The family members of a missing person will experience the additional trauma of ambiguous loss and, as a result, the number of victims of an unidentified death during migration goes far beyond the anonymous bodies that can be counted. Families' agony is further magnified by the many legal and bureaucratic problems they encounter. These include not receiving a death certificate, not being able to claim pensions and property, not being able to remarry or adopt children, and not earning sufficient money to maintain the household (Petrović-Šteger 2009; Parker, London and Aronson 2013).

While one understanding of mourning refers to a set of rituals and practices that creates both personal and collective meaning around death, the trauma of ambiguous loss is precisely the inability to mourn. Lack of knowledge about the loved one gives rise to a challenge to transform

6 See www.missingmigrants.iom.int (accessed 21 November 2018). For a discussion of border death data see Chapters 2,3 and 4 . 
the experience into one with which the family can live. Cognition and rationality often demand a body or another confirmation of death; in its absence, families cannot grieve or make decisions and cannot emotionally accept the permanent absence of a loved one (Wagner 2008; Toom 2018). Situations of ambiguous loss predict symptoms of depression, anxiety and family conflict; the literature also reveals the need of families of the missing to end the ambiguity of loss (Boss 2004, 2018). If surviving family members do not receive official notification and corporeal confirmation of their kin's death, it remains unclear whether someone is dead or alive. The ambiguity of someone's status as absent or present persists. Formal proof of death through identification, burial or repatriation of the body may offer an end to the ambiguity of loss. Informal news of presumed death or shipwreck via known acquaintances can also enable intellectual acceptance of death, 'permitting' families to create space for mourning without feeling they are being unfaithful to the pursuit of their loved one alive (Blaauw and Lähteenmäki 2002). Where the fate of the missing remains ambiguous, some families find their own ways to remember and commemorate the missing in ways that avoid the rituals of mourning that are associated with a death.

As a result of both ambiguous loss and the emergence of digital technologies, new forms of commemoration and memorialization have arisen around the missing. Digital social platforms and mobile media technologies have come to play a new, innovative role in remembering missing persons and in connecting mourners across long distances. Digital images, verses from the Bible and the Qur'an, memories, poems, images and videos of individual commemorative rituals, and YouTube video collages of news images and family photographs are examples of transcontinental mediated commemoration (Horsti 2017). These digital shrines are intended to comfort friends and family in dealing with the impossibility of whispering farewells to missing persons. Yet many of these shrines are accessible around the world and thus become visited by a wider audience that is not related to the dead. Digital shrines act as a proxy for the unknown location where a missing and missed person is, whether or not she is dead or alive. But assuming that many family members will experience moments where someone's death is acknowledged, these online or digital shrines become 'mobile sepulchres' (Petrović-Šteger 2012). A mobile sepulchre instantiates an implosion of boundaries between public and private, local and global, and planned and spontaneous memorialization and commemoration. Digitally mediated routes to memorializing and commemorating those who are 'lost' (i.e. someone who cannot yet be dead), fundamentally transform cultures of remembering, commemorating, reenacting and, therewith, also mourning those who are missing and are missed. 


\section{Concluding thoughts}

There are a number of different realities involved in the tragedy of drowned migrants. First, there is the tragedy of a migrant who drowns while attempting to cross the Mediterranean. Second, the emotional realities experienced by many family members who never receive any corporeal confirmation about the family member's death. We started this contribution with a quote from a report from the Mediterranean Missing research project. Its published reports express the yearning of family members to get back their kin, to be able to bury bones, to have a place to go to, to say prayers at a gravesite, to obtain certainty about someone's place and status, to finally have proof again that a child or parent, sibling or cousin, existed. In another case from the same report, a man longs for his brother: 'We would like his body [...]. Even a part of him, it would relieve us to bury him here in his country among people who know him and love him.' Without a body this man cannot let go of the haunting hope that his brother is still alive. 'A person whom you didn't bury and about whom there's no proof concerning his death, we can't consider him as such. I hate any person who admits that my brother is dead!' (quoted in Ben Attia 2016:14).

When there is a body, it may be unidentified or unknown to the people who receive it on their territory. Such is the case in Italy, where strangers mourn the victims of irregular border crossings. In this situation, we may then think of the migrant's body as one that can be mourned in multiplicity: mourned by those who loved and lost their child, sibling, spouse, or parent; mourned by those who did not know the migrant but see their death as a symbol of injustice; mourned too by believers who feel every person deserves memorializing. Bodies are political objects that can be exploited (Verdery 1999), but they also are cultural subjects and objects, which bring meaning to the living (Laqueur 2015).

A full account of the impact of border deaths on a society must include mourning, for that is the process that shows the emotional consequences of fatal border crossings. While most drowned migrants remain unknown because their bodies are not found, not identified, or buried without a name, we focus on mourning strangers and the impossibility of mourning those who are missing. As discussed, there are varied ways in which the living make meaning around border deaths, including public and private, personal and societal, physical and digital displays of grief and longing. The cemetery, theorized as both a physical and digital space, serves as a primary site for this meaning-making. For the families of missing migrants - potentially, but not confirmed, dead - mourning may be impossible. With further research, we may better understand the trauma this kind of longing to mourn creates. 
We urge researchers to expand the cultural and political cartography of mourning presented here. We urge policymakers and other stakeholders to acknowledge the tragedies triggered by the enormity of not knowing or not being able to mourn in a way that is appropriate for the relatives.

Without a body to say goodbye to, without corporeal certainty of death, the needs, or rights, of families to mourn cannot apply (see Chapter 6). Thus, apart from our abovementioned appeals, we end this contribution by arguing for increased and intensified efforts to locate, recover, examine and administer migrant bodies to facilitate future identification. It is in this context that we welcome initiatives aimed at improving domestic forensic capacities and supporting the further standardization of data related to missing persons (see Chapter 4). While several of such initiatives are developed locally, the problem of missing persons and efforts to identify and repatriate them require an international commitment by individual countries, EU, NGOs and international organizations. With respect to the latter, we applaud a recent initiative from the International Commission on Missing Persons (ICMP) to develop, together with the governments of Cyprus, Greece, Italy and Malta as well as several international organizations, ${ }^{7}$ a joint, standardized and permanent process to account for migrants who are lost on their way to the EU. ${ }^{8}$

\section{References}

Alonso, Alexandra Délano, and Benjamin Nienass. 2016. 'Introduction: Borders and the Politics of Mourning.' Social Research: An International Quarterly, $83(2)$, xix-xxxi.

Albahari, Maurizio. 2016. 'After the Shipwreck: Mourning and Citizenship in the Mediterranean, Our Sea.' Social Research 83 (2), 275-294.

Ben Attia, Frida, Tara Brian, Adrian Carrasco Heiermann, Stefanie Grant, Catriona Jarvis, Iosif Kovras, Frank Laczko, Giorgia Mirto, Katerina Polychroni, Simon Robins, Ann Singleton, and Amal Shaiah. 2016. 'Like a Part of a Puzzle Which Is Missing': The Impact on Families of a Relative Missing in Migration Across the Mediterranean. Report on the Situation of Families. Mediterranean Missing

7 The international organizations are: International Organization for Migration (IOM), Frontex, Interpol, Europol, the United Nations Office of the High Commissioner for Human Rights (OHCHR), the European Network of Forensic Science Institutes (ENFSI), and the International Committee of the Red Cross (ICRC).

8 https://www.icmp.int/press-releases/developing-a-joint-process-on-the-issue-of-missingmigrants-in-the-mediterranean-region/ (accessed 20 December 2018). 
Project. http://openaccess.city.ac.uk/17794/1/Report-on-Families-of-MissingMigrants.pdf (accessed 5 June 2019)

Berns, Nancy. 2011. Closure: The Rush to End Grief and What It Costs Us. Philadelphia, PA: Temple University Press.

Blaauw, Margriet, and Virpi Lähteenmäki. 2002. 'Denial and Silence or Acknowledgement and Disclosure.' International Review of the Red Cross 84 (848), 767-784.

Boss, Pauline. 2004. 'Ambiguous Loss Research, Theory, and Practice: Reflections after 9/11.' Journal of Marriage and Family 66 (3), 551-566.

Boss, Pauline. 2018. 'Families of the Missing: Psychosocial Effects and Therapeutic Approaches.' International Review of the Red Cross 99 (2), 519-534.

Boudreaux, Corrie. 2016. 'Public Memorialization and the Grievability of Victims in Ciudad Juárez.' Social Research 83 (2), 391-417.

Butler, Judith. 2004. Precarious Life. The Powers of Mourning and Violence. London: Verso.

De León, Jason. 2015. The Land of the Open Graves. Oakland: University of California Press.

Edkins, Jenny. 2011. Missing. Persons and Politics. Ithaca and London: Cornell University Press.

Gibbings, Beth. 2010. 'Remembering the SIEV X: Who Cares for the Bodies of the Stateless, Lost at Sea?' The Public Historian 32 (1), 13-30.

Green, Sarah. 2012. 'Absent Details: The Transnational Lives of Undocumented Dead Bodies in the Aegean.' In: The Refugee and Migrant Issue: Readings and Studies of Borders, edited by Sevasti Troubeta, pp. 133-158. Athens: Papazisi.

Horsti, Karina. 2017. 'The Mediated Commemoration of Migrant Deaths at European Borders.' London: Media@LSE Working Paper Series. http://www.lse.ac.uk/ media-and-communications/assets/documents/research/working-paper-series/ EWP46.pdf (accessed 5 June 2019)

Horsti, Karina. 2016. 'Imagining Europe’s borders: Commemorative Art on Migrant Tragedies.' In: Migration by Boat: Discourses of Trauma, Exclusion and Survival, edited by L. Mannik, pp. 83-100. Oxford: Berghahn.

Horsti, Karina, and Klaus Neumann. 2017. 'Memorializing Mass Deaths at the Border: Two Cases From Canberra (Australia) and Lampedusa (Italy).' Ethnic and Racial Studies 42 (2), 141-158.

ICRC. 2010. The Need to Know: Restoring Links Between Dispersed Family Members. Geneva, Switzerland: International Committee of the Red Cross.

Kovras, Iosif, and Simon Robins. 2016. 'Death as the Border: Managing Missing Migrants and Unidentified Bodies at the EU's Mediterranean Frontier.' Political Geography 55, 40-49. 
Laqueur, Thomas W. 2015. The Work of the Dead:A Cultural History of Mortal Remains. Princeton, NJ: Princeton University Press.

Lennon, J. John, and Malcolm Foley. 2000. Dark Tourism. The Attraction of Death and Disaster. London: Continuum.

M'charek, Amade. 2018. “'Dead-Bodies-at-the-Border”: Distributed Evidence and Emerging Forensic Infrastructure for Identification.' In: Bodies as Evidence: Security, Knowledge, and Power, edited by Mark Maguire, Ursula Rao and Nils Zurawski, pp. 89-109. Durham: Duke University Press.

Mirto, Giorgia. 2017. 'La sepoltura delle vittime delle frontiere in Italia.' Università di Pisa, URN etd-07032017-100008.

Parker, Lisa S., Alex John London, and Jay D. Aronson. 2013. 'Incidental Findings in the Use of DNA to Identify Human Remains: An Ethical Assessment.' Forensic Science International. Genetics 7 (2), 221-229.

Perl, Gerhild. 2016. 'Uncertain Belongings: Absent Mourning, Burial, and Postmortem Repatriations at the External Border of the EU in Spain.' Journal of Intercultural Studies 37 (2), 195-209.

Petrović-Šteger, Maja. 20o9. 'Anatomising Conflict - Accommodating Human Remains.' In: Social Bodies, edited by Maryon McDonald and Lambert Helen, pp. 47-76. Oxford: Berghahn.

Petrović-Šteger, Maja. 2012. 'Mobile Sepulchre and Interactive Formats of Memorialization: On Funeral and Mourning Practices in Digital Art.' Journeys 13 (2), 71-89. https://www.doi.org/10.3167/jys.2012.130206

Robins, Simon. 2010. 'Ambiguous Loss in a Non-western Context: Families of the Disappeared in Post-conflict Nepal.' Family Relations 59 (3), 253-268.

Robins, Simon, Iosif Kovras, and Anna Vallianatou. 2014. Addressing Migrant Bodies on Europe's Southern Frontier: An agenda for research and practice. Queen's University Belfast and Centre for Applied Human Rights, University of York. http://www.simonrobins.com/Policy\%2obrief\%20-\%2oAddressing\%20 migrant\%2obodies\%2oin\%2othe\%2oEU.pdf (accessed 5 June 2019)

Rosenblatt, Adam. 2015. Digging for the Disappeared: Forensic Science after Atrocity. Stanford: Stanford University Press.

Rygiel, Kim. 2016. 'Dying to Live: Migrant Deaths and Citizenship Politics Along European Borders: Transgressions, Disruptions, and Mobilizations.' Citizenship Studies 20 (5), 545-560.

Schwartz-Marin, Ernesto and Arely Cruz-Santiago. 2016. 'Pure corpses, dangerous citizens: Transgressing the boundaries between experts and mourners in the search for the disappeared in Mexico.' Social Research: An International Quarterly, $83(2), 483-510$.

Stierl, Maurice. 2016. 'Contestations in Death - the Role of Grief in Migration Struggles.' Citizenship Studies 20 (2), 173-191. 
Tapella, Amelie, Giorgia Mirto and Tamara Last. 2016. 'Deaths at the Borders. From Institutional Carelessness to Private Concern. Research Notes from Italy.' Intrasformazione: Rivista di Storia delle Idee 5 (1), 57-64.

Toom, Victor. 2018. 'Finding Closure, Continuing Bonds, and Codentification After the 9/11 Attacks.' Medical Anthropology: Cross Cultural Studies in Health and Illness 37 (4), 267-279. https://www.doi.org/10.1080/01459740.2017.1337118

Toom, Victor. 2016. 'Whose Body Is It? Technolegal Materialization of Victims' Bodies and Remains After the World Trade Center Terrorist Attacks.' Science, Technology \& Human Values 41 (4), 686-708. https://www.doi.org/10.1177/0162243915624145 Verdery, Katherine. 1999. The Political Lives of Dead Bodies: Reburial and Postsocialist Change. New York: Columbia University Press.

Wagner, Sarah E. 2008. To Know Where He Lies. DNA Technology and the Search for Srebrenica's Missing. Berkeley: University of California Press.

\section{About the authors}

Giorgia Mirto is an independent researcher with a background in peace studies and a consultant for the ICRC. Since 2011, she has developed expertise on issues relating to missing migrants and border deaths in Italy through her empirical contributions to several prominent research projects.

Simon Robins combines academic research with a humanitarian consulting practice focusing on policy and programme support with international agencies and NGOs, with an emphasis on states emerging from conflict and violence. He is Senior Research Fellow at the Centre for Applied Human Rights at the University of York.

Karina Horsti is Senior Lecturer and Academy of Finland Fellow at the University of Jyväskylä. She has a background in media studies and has developed a multidisciplinary profile in transnational migration research. Her current research examines public remembering of forced migration and the commemoration of deaths at Europe's borders.

Pamela Prickett is an urban ethnographer and Assistant Professor of Sociology at Universiteit van Amsterdam. She completed her doctorate at UCLA and postdoctoral research at Rice University, where she serves as a Fellow in the Religion and Public Life Program. Previously, she worked as a journalist and media professional. 
Deborah Ruiz Verduzco is Head of Civil Society Initiatives at the International Commission for Missing Persons. She holds a PhD in international law and has previously worked with the Assembly of States Parties of the International Criminal Court, Parliamentarians for Global Action, and several state institutions in Mexico.

Victor Toom works at the Dutch Health Council. Previously, he was a Marie Curie Fellow at the Institute of Sociology, Goethe-Universität Frankfurt a.M., and a Leverhulme Trust Early Career Researcher at the Centre for Forensic Science, Northumbria University. His research addresses forensic identification practices after mass human fatality incidents. 